\title{
Fábián, Katalin and Korolczuk, Elzbieta (eds.). 2018. Rebellious Parents: Parental Movements in Central-Eastern Europe and Russia. Bloomington: Indiana UP. 364 pp.
}

\author{
Reviewed by Erika Kispéter ", University of Warwick, U.K.
}

The present book is an edited volume of articles focusing on parental movements that have emerged in the last few decades in post-communist East-Central Europe and Russia. Parental movements are loosely defined as movements that mobilize people on the basis of their identities and experiences as parents, including formal organizations and informal networks acting on- and offline. Therefore, in this volume the authors aim at offering new empirical observations and theoretical conceptualizations of parental activism and thus to contribute to scholarship on social activism and civil society in both this region and on a wider, global scale. The volume editors are Katalin Fábián, a researcher of government and law working in the U.S., who has most recently edited a volume on domestic violence in post-communist states, and sociologist Elzbieta Korolczuk, who works in Warsaw and Stockholm and has already co-edited several volumes on parenthood and politics. Both the editors and the other authors have been long-term inhabitants and observers of the countries they write about, and their familiarity with the broader contexts and finer details of their case studies clearly comes through in their studies.

My first impression of the volume was that it is about the kind of activists that I as a gender researcher spend my waking hours debating with and would happily avoid, like, for example, conservative parents' groups in Russia acting against legal changes that could promote gender equality, or divorced fathers in the Czech Republic and Poland arguing against the "feminization" of society and opposing the ratification of legislation that combats violence against women, or parents anywhere in the region who resist mandatory vaccination of small children. As Korolczuk and Renata E. Hryciuk, in their chapter on fathers' activism in Poland (113-144) describe, they, too, faced epistemological and moral challenges while studying parental movements whose values they oppose. In any case, while not all chapters focus on conservative movements, the majority do. In fact, the editors argue that even their not so large selection of case studies demonstrates how, in the past two decades, conservative nationalist imagery has spread among parental movements across East-Central Europe. Moreover, this development is but one of many other and similar political shifts that are nowadays taking place in both the national and the transnational realms of the region.

The volume includes eleven case-study chapters divided into three sections. The first section (Chapters 1-3) discusses conservative-nationalist parental movements in Russia, the

\footnotetext{
*E.Kispeter@warwick.ac.uk
}

$($ (c) $)$ EY

ULIS D-Sente
New articles in this journal are licensed under a Creative Commons Attribution 4.0 International License.

This journal is published by the University Library System of the University of Pittsburgh as part of its D-Scribe Digital Publishing Program and is cosponsored by the University of Pittsburgh Press 
Kispéter, Erika. "Fábián, Katalin and Korolczuk, Elzbieta (eds.). 2018. Rebellious Parents: Parental Movements in Central-Eastern Europe and Russia. Bloomington: Indiana UP. 364 pp.” Hungarian Cultural Studies. e-Journal of the American Hungarian Educators Association, Volume 11 (2018) DOI: 10.5195/ahea.2018.337

Ukraine and Bulgaria. The second (Chapters 4-7) examines fathers' activism in Poland, Russia, Ukraine and the Czech Republic, focusing on the changing status and social perception of fatherhood and its relations with gender equality. The third and final section (Chapters 8-11) offers analyses of health-related activism (e.g., assisted reproduction, home birth and child vaccination) in the Czech Republic, the Baltic States, and Hungary. Thus the book concentrates more on the social and political contexts of parental movements in Russia, Ukraine, and the Czech Republic, while these issues in Poland, Hungary and Bulgaria are dealt with only in one chapter for each of these three countries, and all three Baltic States are likewise treated in a single chapter.

The most important conclusion emerging from the case studies in Fábián and Korolczuk's edited volume is that parental activists maintain ambiguous attitudes toward the following entities: the state and its policies, institutions and standpoints; the "individualist West" as invariably described by the activists; and gender-equality policies as adopted by the EU, the UN and by some post-socialist states. The two editors argue that the parental movements' strategic utilization of these ambiguities is successful: they can use local and transnational opportunity structures to their benefit and influence local policy environments. Furthermore, the ambiguous standpoints of post-socialist parental movements enable them to entertain a highly adaptable approach to politics: "they engage in political activism while simultaneously challenging and redefining what politics and civic engagement mean" (9).

On the theoretical level, and more importantly for the region at the volume's focus, this collection aims at bringing the perspectives of theories on civil society and social movements closer to the empirical landscape of post-socialist East-Central Europe. While most authors attempt to go beyond empirical analysis, the depth of their engagement with theoretical debates varies a great deal across the chapters, with the key theoretical contribution of this volume always remaining that it expands the dominant conceptualizations of civil society beyond the more familiar Western setting for such investigations.

As said, there is only one chapter in the book that focuses on Hungary. In this chapter (308-334) Katalin Fábián describes how the grassroots network of parents involved in home birth became a movement, and a rather successful one, almost overnight, when midwife, psychologist and active advocate of home birth Ágnes Geréb was arrested in 2010 following two home births she managed, in 2000 and 2007, that ended with the deaths of the infants. Using the method of visual-content analysis of the materials produced by the activists, Fábián has produced a chapter that is likely to offer something new and interesting even to those of us who are familiar with the recent history of Hungarian home-birth activism. My only critical comment on this chapter is that the more theoretically oriented analysis presented in it could be even further developed.

Having read Rebellious Parents, I could say that a number of issues discussed in it, such as "demographic nationalism" and the struggle for the rights of divorced fathers, will be familiar to Hungarian readers. As for myself as one of them, I would say that thanks to the insightful analyses of these phenomena as presented in this volume, I now feel less puzzled about the emergence of certain reactionary parental movements in Hungary. For me, the volume's most compelling aspect is that several of its chapters trace how the discursive frames and strategies used by parental movements in the region are linked to the socialist past of the state in question and embedded in its national and transnational ideologies and practices. 
Kispéter, Erika. "Fábián, Katalin and Korolczuk, Elzbieta (eds.). 2018. Rebellious Parents: Parental Movements in Central-Eastern Europe and Russia. Bloomington: Indiana UP. 364 pp." Hungarian Cultural Studies. e-Journal of the American Hungarian Educators Association, Volume 11 (2018) DOI: 10.5195/ahea.2018.337

While the case studies and methodologies for dealing with the diversity of the parental movements included in the volume do not allow for systematic comparisons across countries, some patterns of similarities and differences among these countries certainly emerge. For example, I have found the four chapters discussing fathers' activism in different East-Central European countries particularly interesting when read together. American gender researcher Nanette Funk's back-cover blurb describes this book as a study that "challenges stereotypes and presents new areas of valuable research," to which I would add that it is also a thought provoking, timely and highly relevant collection. 